\title{
Unfortunate fate of a common man, reflected through Arthur Miller's Death of a Salesman, a Comparative Study
}

\author{
Anisha Singh ${ }^{1}$, S.K. Singh ${ }^{2}$ \\ 1.ABES Engineering College, UPTU,Ghaziabad, India, \\ 2. Lingaya's University, Faridabad, India.
}

\begin{abstract}
The objective of this study is to explore the different modes and images of tragic vision of the great American dramatist, Arthur Miller, as manifested in his dramas. The study also consist the comparative observation of another dramatists after and before Millers plays. The study mainly deals with the drama outlined in the course of a common man but all other major dramas from the pen of other dramatist shall also be taken in view, where necessary.

The aim is to find contemporary dimensions that happens in real life and that reveals in the form of tragedy of a common man through drama. The paper analyses the tragedy of a common man through, the great American dramatist Arthur Miller's "Death of a Salesman". An effort shall also be made to co-relate various facts of Miller's tragic vision along with another author's views in the present research study.
\end{abstract}

Key Words: Tragic vision, guilt, criss-cross, protagonist, melodrama, the tragicomic and epic,

\section{Introduction}

From the time of Greek tragedy, the pattern of tragic action has been almost uniform in being centered around the awakening of the tragic protagonist to a sense of wrong doing on his own part. In this, therefore, Miller's interest in the subject of guilt is traditional and follows the usual pattern of wrong- doing and its aftermath. The five constituents of the tragedy- Individual, Family, Society, Church and state-are so interlocked in a grim, relentless struggle that the criss-cross of conflicting loyalties presents a most challenging test of the protagonist's moral fiber. And it's in the quality of his defiance that the greatness of tragedy lays.

Since Arthur Miller believes in conveying ideas, even morals, through his plays, he seems to be cautioning the reader in his dramas that if a tragedy is to be averted in life, the world of the manifest should not be perpetuated at the cost of the hidden, that reality can be hidden only for a short time, not for ever[1]. Today, people do not often see the unquestionable splendor of royalty, the unrelenting actions of the hand of fate, or the importance of human interactions. Does it mean that a tragic hero could not exist in the modern world? My answer will yes, they exist, and to establish this, the various facts are correlated through this study. Science world war $2^{\text {nd }}$ and 1950 's, people focused on pursuit of happiness. Life and liberty seems to taken care of. Miller undertook to examine American society and its soul-shriveling materialism, and the process shows us far more than the business of the Dream. Miller for eternity shows his dream by a common man. The history of the theatre in America begins early in the Eighteenth Century, about the time the first rumblings were heard of the storm which was to break the ties still holding the Colonies to the mother country.

As it is earlier said the objective of this learning is to the relative study of Miller's (Death of a Salesman) with other dramatist, and in this quest, the play of Eugene O'Neill, Long Day's Journey into Night, came so shortly after Miller's Death of a Salesman. To highlight why with the passing decades, Miller's Death of a Salesman need comparison to other dramas, reason behind this is that, due to increasing number of interested readers Miller's tragedy seems to lost the attraction among them. I contrast its techniques and construction with those of its most powerful contemporary, Eugene O'Neill's Long Day's Journey Into Nigh [2].The links between these two plays are not merely chronological. Both focus intensively on an American family seemingly at the edge of ruin; each family centers almost exclusively on the mother, father, and their two sons, living together though all the boys are well past college age. Both plays further suggest that their family comments deeply on the evolution of modern American society, strained between ideals of love and blind forces of oppressive economic determinism. What makes these two plays seem, today, so radically different from each other? The answer will establish the grounds of the concluding attempt to situate Death of a Salesman within an adjusted critical framework. Academic approaches to modern drama have been relatively unaffected, even neglected, by the upsurge over the past 30 years of "critical theory." [3].

The reason for this relative neglect is easy to discern. Poems and prose works exist as words on a page that invite continual re-examination by critical theories which in common challenge the notion that words can be fixed into meaning by representational reference. The "garden" in a poem or story, we have learned, need not relate to a garden in the life-world of objective reality; it can be considered indefinitely as a role within a 
network of other words that together create their own reality. The garden in Death of a Salesman, however, always at least refers to a concrete representation in a performance of that play-to the interaction of sets, lighting, props, and actual stage actions by actual people uttering the words in contexts fulfilled by each performance. The play-text is merely one component in any play; the other principal component is its history of performances, each one of which concretizes an interpretation that must be seen and not merely imagined. Drama is the ritual enactment of words. Its words are staging directions activating actual events and scenes set before an audience. A Theater people have known and worked with that knowledge from the very beginnings of drama in pre-literate times. It's old-hat to them, and only part of the story, anyway. The strongest plays continue to be performed precisely because they acknowledge only too well the indeterminateness of meaning in every play-text [4].

Hence dramatic criticism labors still with issues of generic distinctions, whereby the nature of "tragedy" remains a compelling subject for continued analysis. If we define tragedy in the words of Aristotle it is as: A tragedy is the imitation of an action that is serious, and also as having magnitude, complete in itself in language with pleasurable accessories, each kind brought in separately in the parts of the work; in a dramatic, not in a narrative form: with incidents arousing pity and fear; wherewith to accomplish its catharsis' of such emotions.

Miller's play continues to be taught and performed in public high schools, colleges, community theatres, and universities alike. An interesting element about Death of a Salesman is that some critics (all late 20th century) claim that Miller's early plays were popular for the singular reason that they were provocative during their own time, but no longer deserve this classical status.

When Miller in his essay explains that the unchangeable environment leads to terror and fear, and terror and fear leads to tragedy: In the play, the unchangeable environment is society and his family.

Terror and fear is that of his fear to admit his failures, and tragedy is his death at the end. When the author states that tragedies shake readers because of the main fear of being torn away from the identity/image we desire to have: This is a lot like Willy in that Willy too was scared of being seen as a failure and not a salesman worthy of a death like Dave Singleman[7,8]. It seems that Willy wanted to be an amazing businessman who knew everyone and was well liked by everyone. He wanted to be a success. However, as he was unable to do so and become truly what he desired to be, the tragedy is seen.

To Miller, what constitutes the true content of a tragedy is not the 'rank' or 'position' of the hero, but the sincerity of his commitment, intensity of fortitude and depth of emotions displayed at a moment of great crisis and humiliating situations which threaten to snatch his entity and identity. He further asserts that: "From Orestes to Hamlet, Medea to Macbeth the underlying struggle is that of an individual attempting to secure his 'rightful' position in the society."

\section{Materials and methods}

How can Miller's Death of a Salesman be called a tragedy and yet be interpreted in so many different fashions? The answer if now clear: the generalized expansion of what "tragedy" means enfeebles its decisiveness as a useful critical tool. I will begin with Miller's own notion of the tragic, and then survey representative diverse commentaries in which the term "tragedy" has sponsored the current critical disagreements.

In the modern era, tragedy has also been defined against drama, melodrama, the tragicomic and epic theatre. The character and plot in most of Tragedies are linked up. In Greek Tragedies fate played a very important part, but after the Renaissance character became more and more prominent. In some of Shakespearian Tragedies, despite the importance of character, the motivation of action comes from the supernatural forces or even external circumstances. In modern Tragedies, the hero is often the victim of social forces[10].

The history of the theatre in America begins early in the Eighteenth Century, about the time the first rumblings were heard of the storm which was to break the ties still holding the Colonies to the mother country.

Sixty years ago this past April, Arthur Miller's Death of a Salesman opened in New York. The press notices registered positive reactions to its concentrated power, its bold use of intermixed time-frames, its twotiered set and imaginative lighting, and its important themes. Not infrequently, terms like "tragedy" and "tragic" surfaced. No viewer could have doubted its emotional seriousness; as Stanley Kauffmann noted, "the play bristles with spears of pathos that no critical shield can deflect". Some voices even suggested that this play would open a new direction for the evolution of American drama.

Arthur Miller's Death of a Salesman can be seen as an eulogy of a dreamer, which depicts one man's tragic life and death as he tries to bring his family into grace. Miller does, however, also uses this play to express underlying themes and ideas. Reading Death of a Salesman from the starting point of a Marxist results in the perception that miller uses his play as a means to demonstrate the effects of a changing capitalist society. On the other hand, a psychological reading of Death of a Salesman allows the play to be seen as one mans flight from shame and his own weakened self image [11,12]. 
In Death of Salesman, Miller countered that the right to be the deplorable tragic hero shouldn't only have a place with individuals to honourable life commencement. All the more the normal man could be the courageous person of a tragedy. Underlying the play is a conviction that the regular man is as adept a subject for tragedy in its most elevated sense as rulers were. This plainly shows that the sort called tragedy has experienced a huge change in the twentieth century $[13,14]$.

\section{Conclusion}

Death of a Salesman is regarded by scholars, critics, and theatergoers as the quintessential American drama, it is also one of the most translated and performed plays in the world. Many critics suggest about this drams (Death of a Salesman), that is a critique of a capitalist society that brutalizes the unsuccessful. While the sociopolitical textures of the play are present, however, Death of a Salesman gains its power from additional sources.

When Arthur Miller says that tragedy enlightens and has to point "the heroic finger at the enemy of man's freedom": This was like the play in that at the end, the tragedy doesn't seem all too bad because through it, the family learns a lot. Even though Willy died, and it's a sad thing, the tragedy seems to show what the underlying problem was, and it seems to also hint at a new beginning. Similar to the above point, when Miller states that "Tragedy must preach revolution": It is possible to see the connection to the play with this in that at the end, although tragic, there is a revolution in that the family is now free and capable of starting a new life.

\section{Acknowledgement}

We acknowledge Mrs. Madhu Rani for her valuable advice.

\section{References}

[1] Miller, A. Death of a Salesman. New York: Penguin Books, 1949.

[2] O’Neill, Eugene. Long Day’s Journey into Night. New Haven: Yale University Press, 1956.

[3] Mamdouh Imara, "Self and Society in Arthur Miller's Plays." Tishreen University Journal: Literature and Humanities Series 3 (1993): 98-111, Syria

[4] W. E. Modern American Drama 1945-1990. London: Cambridge University 5.Press; 1992.

[5] Moss, Leonard. "The Unrecognized Influence of Hegel's Theory of Tragedy." The Journal of Aesthetics and Art Criticism. 28 (1969):91-97.

[7] W. Denis. A. Miller. London: Oxford U. Press; 1973.

[8] Madhu Rani, “ Tragedic vision in Arthur Miller's Death of Salesman”. An Intenational Biannual Journal of English studies, Volume2, Nov.1, no.1,2005.

[9] M. Edward. Miller A: Dramatist. New York: Ungar, 1967

[10] Martine, James J. Critical Essays on A Miller. Boston: G.K. Hall and Co.1979.

[11] Miller, A. Salesman in Beijing. New York: Viking Press, 1984

[12] Shrivastva, R. K., Critical Studies in English and American Literature. New Delhi: ABS Publication; 1993.

[13] W. Denis. A. Miller. London: Oxford U. Press; 1973.

[14] Kritika Nanda "Common Man As A Tragic Hero: A Study Of Arthur Miller's Death Of A Salesman" Indian Streams Research Journal Vol-3, Issue-10 (Nov 2013) 